\title{
Mixed Infection in Adult Post-neurosurgical Bacterial Meningitis: A Hospital-based Study
}

\author{
Wei-An Lai, Cheng-Hsien Lu, Wen-Neng Chang
}

Background: Post-neurosurgical (post-NS) adult bacterial meningitis $(\mathrm{ABM})$ with mixed infection is rarely examined solely in the literature.

Methods: The clinical features and laboratory data of post-NS ABM patients with mixed infection were included for analysis.

Results: $\quad$ Totally 170 post-NS ABM cases were identified and 18 (11 men and 7 women, aged 20-77 years, median $=57.5$ ) of them had a mixed infection. A total of 45 bacterial strains including 34 Gram-negative [Gm(-)] strains and 11 Gram-positive $[\mathrm{Gm}(+)]$ strains were isolated. Of the implicated pathogens, Escherichia coli, Acinetobacter, Pseudomonas, and Klebsiella spp. were the common Gm(-) strains, while staphylococcal, streptococcal, and enterococcal strains were the common $\mathrm{Gm}(+)$ strains. Compared with the post-NS ABM cases with monomicrobial infection, those with mixed infection had a lower cerebrospinal fluid (CSF) white blood cell count. The mortality rate of post-NS ABM cases was $33.3 \%(6 / 18)$ without significant clinical and laboratory difference between the fatal and non-fatal groups.

Conclusion: Mixed infection is not uncommon in post-NS $\operatorname{ABM}(10.6 \%, 18 / 170)$, and its mortality rate is high.

Seventy-six percent of the implicated bacterial pathogens belonged to Gm(-) strains, while the other $24 \%$ were $\mathrm{Gm}(+)$ strains. The clinical and laboratory features of ABM with mixed infection are not unique; its diagnosis can only be confirmed by a positive CSF culture. (Biomed J 2013;36:295-303)

\section{At a Glance Commentary \\ Scientific background of the subject}

Mixed infection in adult bacterial meningitis (ABM), especially in those with a post-neurosurgical (post-NS) state has been rarely examined solely in the literature. In this study we examined the clinical and laboratory characteristics and therapeutic outcome of this specific infectious syndrome.

\section{What this study adds to the field}

Mixed infection is not uncommon in post-NS ABM and Gm(-) pathogens have outnumbered the $\mathrm{Gm}-(+)$ pathogens as the implicated pathogens of this specific infectious syndrome. A high suspicion of this infectious disease is needed for early identification because its diagnosis can only be confirmed by positive CSF culture.

\section{Key words: adult bacterial meningitis, mixed infection, post-neurosurgical}

$\mathrm{U}$ nlike focal suppuration, adult bacterial meningitis (ABM) is typically of monomicrobial infection. ${ }^{[1-5]}$ Previously, only about $1 \%$ of overall bacterial meningitis cases were caused by more than one bacterial species, and before 1950, most of the bacterial meningitis with mixed infection occurred in pediatric group. ${ }^{[5]}$ But after 1950, more mixed infection in bacterial meningitis occurred in adult patients, ${ }^{[1,4,5]}$ and in recent years, its incidence has increased gradually. In one study of overall ABM reported in 2008 by Chang et al. ${ }^{[1]}$ the incidence of ABM with mixed infection accounted for $8.84 \%(16 / 181)$, and in their previous study reported in $2000,{ }^{[4]}$ they found that $75 \%(9 / 12)$ of ABM cases with mixed infection had a post-neurosurgical (post-NS) state as the underlying condition, and most of the implicated pathogens had a high incidence of antibiotic resistance. The epidemiology of ABM can be changed by several fac-

From the Department of Family Medicine and Department of Neurology, Kaohsiung Chang Gung Memorial Hospital and Chang Gung University College of Medicine, Kaohsiung, Taiwan

Received: Aug. 20, 2012; Accepted: Jan. 11, 2013

Correspondence to: Dr. Wen-Neng Chang, Department of Neurology, Kaohsiung Chang Gung Memorial Hospital. 123, Dapi Rd., Niaosong, Kaohsiung 833, Taiwan (R.O.C.). Tel: 886-7-7317123 ext. 2283; Fax: 886-7-7333816; E-mail: cwenneng@ ms19.hinet.net

DOI: $10.4103 / 2319-4170.113368$ 
tors including various time periods of study, geographic distribution, age, race, underlying medical and/or neurosurgical (NS) conditions, means of contraction, status of vaccination, and use of antibiotics in community. ${ }^{[1,2]}$ This epidemiologic change may influence the choice of appropriate antibiotics which is an important strategy for a successful ABM management. ${ }^{[1,2,6-13]}$ Management of post-NS ABM is a therapeutic dilemma because of its complicated NS procedures, diagnostic confirmation of bacterial meningitis, and choice of appropriate antibiotics, especially when facing the mixed infection state. ${ }^{[1,4,14-17]}$ Therefore, we analyzed the clinical and laboratory characteristics of 18 post-NS ABM cases with mixed infection, collected during a study period of 11 years, in order to offer a better view of this uncommonly reported central nervous system (CNS) infection.

\section{METHODS}

The medical and microbiological records of cerebrospinal fluid (CSF) of all adult patients with bacterial meningitis admitted to our hospital from 2000 to 2010 were retrospectively reviewed. Our hospital is the largest teaching hospital in southern Taiwan and is a 2482-bed acute-care teaching hospital providing both primary and tertiary care services. This study was approved by the Ethics Committee of Chang Gung Memorial Hospital (IRB 100-0323C).

In this study, the criteria used for a definite diagnosis of ABM are as follows: ${ }^{[1,2]}$ (a) age $\geq 17$ years; (b) positive CSF culture in patients with clinical presentations of acute bacterial meningitis, including fever, headache, altered consciousness, and seizure; and (c) at least one of the following CSF parameters: (1) a leukocyte count $>0.25 \times 10^{9} / \mathrm{L}$ with predominant polymorphonuclear cells; (2) a CSF lactate concentration $>3.5 \mathrm{mmol} / \mathrm{L}$; or (3) a glucose ratio $(\mathrm{CSF}$ glucose/serum glucose) $<0.4$ or CSF glucose concentration $<2.5 \mathrm{mmol} / \mathrm{L}$ if no simultaneous blood glucose was determined. Coagulase-negative staphylococci were considered to be pathogenic when positive cultures were noted in $\geq 2$ separate CSF studies or one positive CSF culture was obtained from the tip of an indwelling NS device. ${ }^{[17]}$

In this study, "nosocomial" meningitis was defined as a positive bacterial infection not present when the patient was admitted to the hospital, clinical evidence of an infection $>48 \mathrm{~h}$ after admission, or clinical evidence of meningitis within 1 month after discharge from the hospital where the patient had received an invasive procedure, especially an NS procedure. Otherwise, the patient was considered to have "community-acquired" infection. Meningitis related to traumatic skull fracture, NS procedure, or any causes of skull defects was classified as "post-NS" form. Otherwise, patients were classified as the "spontaneous" form. Patients were considered to have mixed infection if at least two bacterial organisms were isolated concomitantly from the initial
CSF cultures. ${ }^{[4]}$ "Superinfection" in ABM was defined as a condition wherein CSF grew new pathogen(s) during the therapeutic course of existing bacterial meningitis. ${ }^{[15]}$ Both the mixed infection and superinfection were classified in the polymicrobial infection. In this study, the analysis of antibiotic susceptibility was based on the National Committee for Clinical and Laboratory Standards/Clinical and Laboratory Standards (NCCLS/CLS) methods. Intermediate and resistant isolates were considered non-susceptible. ${ }^{[18]}$ In the study period, vancomycin plus a $3^{\text {rd }}$ or $4^{\text {th }}$ generation cephalosporin were the initial empiric antibiotics used in the treatment of patients with suspected ABM in our hospital, and the antimicrobial regimen was adjusted subsequently after the culture results were made available.

For comparative analysis, the clinical features of the post-NS ABM patients with mixed infection were compared with those of post-NS ABM patients with single pathogen infection. Meanwhile, the clinical characteristics and laboratory data between the fatal and non-fatal cases of the mixed infection group were also compared. The clinical data including gender, underlying condition, clinical presentations, and therapeutic outcome were analyzed by Fisher's exact test. The data of age, CSF white blood cell count, glucose level, total protein, and lactate were compared using the Mann-Whitney U test. A $p<0.05$ was considered statistically significant.

\section{RESULTS}

During this study period, a total of 261 ABM cases were identified, and among them, 170 belonged to post-NS meningitis cases. The 170 post-NS ABM cases included 133 cases with a monomicrobial infection and 37 cases with a polymicrobial infection. Among the latter 37 cases, 16 had mixed infection, 19 had superinfection, and 2 had both mixed infection and superinfection, i.e., a total of 18 cases had the condition of post-NS ABM with mixed infection. In this study, the clinical and laboratory characteristics of the 18 post-NS ABM cases with mixed infection were analyzed, and for a comparative purpose, the clinical and laboratory characteristics of the other 133 post-NS ABM cases with monomicrobial infection were also analyzed.

The 18 post-NS ABM cases with mixed infection consisted of 11 men and 7 women, aged 20-77 years (median $=57.5$ ), and their clinical and laboratory information are listed in Table 1 . The underlying NS conditions of these 18 cases of $\mathrm{ABM}$ with mixed infection were spontaneous intracranial hemorrhage $(\mathrm{ICH})+\mathrm{s} / \mathrm{p}$ craniotomy + external ventricular dranage (EVD) in three cases (cases 5, 12, and 17), spontaneous ICH + s/p EVD in two cases (cases 14 and 18), spontaneous ICH + s/p craniectomy + ventriculoperitoneal (VP) shunt + cranioplasty in one case (Case 2), spontaneous ICH + s/p craniectomy + EVD in one case (Case 3 ), 
Table 1: Pathogens, underlying condition, clinical presentations, antibiotic treatment, and prognosis of the 18 patients with mixed infection of bacterial meningitis

\begin{tabular}{|c|c|c|c|c|c|c|c|}
\hline Patient & Age/gender & Pathogens & Underlying condition & Clinical presentations & Management & Antibiotics & Survived \\
\hline 1 & $57 / \mathrm{F}$ & $\begin{array}{l}\text { Escherichia coli, } \\
\text { Elizabethkingia } \\
\text { meningoseptica }\end{array}$ & $\begin{array}{l}\text { DM, acute ischemic } \\
\text { stroke, craniectomy }\end{array}$ & $\begin{array}{l}\text { Fever, altered } \\
\text { consciousness, } \\
\text { seizure, brain abscess, } \\
\text { leukocytosis }\end{array}$ & Craniectomy & $\mathrm{ROC}, \mathrm{CIP}$ & No \\
\hline 2 & $40 / \mathrm{M}$ & $\begin{array}{l}\text { Escherichia coli, } \\
\text { Enterococcus, Klebsiella } \\
\text { oxytoca, Pseudomonas } \\
\text { aeruginosa, Bacteroides } \\
\text { distaonis*, Bacteroides } \\
\text { uniformis* }\end{array}$ & $\begin{array}{l}\text { SAH, craniectomy, VPS, } \\
\text { cranioplasty }\end{array}$ & $\begin{array}{l}\text { Fever, seizure, } \\
\text { hydrocephalus }\end{array}$ & $\begin{array}{l}\text { EVD (removal } \\
\text { of VPS) }\end{array}$ & $\begin{array}{l}\text { VA, CAZ, } \\
\text { MET }\end{array}$ & Yes \\
\hline 3 & $64 / \mathrm{F}$ & $\begin{array}{l}\text { Escherichia coli, } \\
\text { Enterococcus spp. }\end{array}$ & $\begin{array}{l}\text { DM, RHD, SICH, } \\
\text { craniectomy, EVD }\end{array}$ & $\begin{array}{l}\text { Fever, hydrocephalus, } \\
\text { leukocytosis }\end{array}$ & $\begin{array}{l}\text { EVD (removal } \\
\text { of old EVD) }\end{array}$ & VA, CAZ & No \\
\hline 4 & $34 / \mathrm{M}$ & $\begin{array}{l}\text { Staphylococcus } \\
\text { chromogenes, } \\
\text { coagulase-negative } \\
\text { staphylococci }\end{array}$ & $\begin{array}{l}\text { TICH, craniectomy, VPS, } \\
\text { cranioplasty }\end{array}$ & $\begin{array}{l}\text { Abdominal wound } \\
\text { infection (VPS) }\end{array}$ & $\begin{array}{l}\text { EVD (removal } \\
\text { of VPS) }\end{array}$ & LZD & Yes \\
\hline 5 & $63 / \mathrm{M}$ & $\begin{array}{l}\text { Citrobacter freundii, } \\
\text { Escherichia coli }\end{array}$ & SAH, craniotomy, EVD & Fever, hydrocephalus & Removal of EVD & MEP & Yes \\
\hline 6 & $50 / \mathrm{F}$ & $\begin{array}{l}\text { Enterobacter cloacae, } \\
\text { Klebsiella pneumoniae }\end{array}$ & $\begin{array}{l}\text { Acute ischemic stroke, } \\
\text { craniectomy, EVD }\end{array}$ & Fever, hydrocephalus & Removal of EVD & MAX & Yes \\
\hline 7 & $26 / \mathrm{M}$ & $\begin{array}{l}\text { Staphylococcus aureus, } \\
\text { Prevotella spp.* }\end{array}$ & TICH, craniotomy, VPS & Fever, seizure & Removal of VPS & LZD & No \\
\hline 8 & 77/M & $\begin{array}{l}\text { Acinetobacter junnii, } \\
\text { Staphylococcus } \\
\text { epidermidis }\end{array}$ & DM, old head injury, VPS & $\begin{array}{l}\text { Fever, hydrocephalus, } \\
\text { leukocytosis }\end{array}$ & Removal of VPS & $\mathrm{VA}, \mathrm{CAZ}$ & Yes \\
\hline 9 & $67 / F$ & $\begin{array}{l}\text { Alcaligenes faecalis, } \\
\text { Brevundimonas diminuta, } \\
\text { Comamonas acidovorans }\end{array}$ & DM, stroke, EVD & Fever, hydrocephalus & Removal of EVD & MEP & Yes \\
\hline 10 & $44 / \mathrm{M}$ & $\begin{array}{l}\text { Escherichia coli, } \\
\text { Pseudomonas } \\
\text { aeruginosa, } \\
\text { Streptococcus } \\
\text { pneumoniae }\end{array}$ & TICH, craniotomy, VPS & $\begin{array}{l}\text { Fever, altered } \\
\text { consciousness, } \\
\text { seizure, } \\
\text { hydrocephalus, brain } \\
\text { abscess, leukocytosis }\end{array}$ & $\begin{array}{l}\text { EVD (removal } \\
\text { of VPS) }\end{array}$ & VA, CAZ & Yes \\
\hline 11 & $30 / \mathrm{M}$ & $\begin{array}{l}\text { Acinetobacter buamannii, } \\
\text { viridian streptococcus }\end{array}$ & $\begin{array}{l}\text { TICH, craniectomy, } \\
\text { cranioplasty, EVD }\end{array}$ & $\begin{array}{l}\text { Fever, altered } \\
\text { consciousness, } \\
\text { leukocytosis }\end{array}$ & $\begin{array}{l}\text { EVD (removal } \\
\text { of old EVD) }\end{array}$ & VA, MEP & Yes \\
\hline 12 & $59 / \mathrm{M}$ & $\begin{array}{l}\text { Acinetobacter spp., } \\
\text { Brevundimonas diminuta }\end{array}$ & SAH, craniotomy, EVD & $\begin{array}{l}\text { Fever, shock, } \\
\text { hydrocephalus, } \\
\text { leukocytosis }\end{array}$ & Removal of EVD & MEP & No \\
\hline 13 & $77 / \mathrm{F}$ & $\begin{array}{l}\text { Bacteroides fragilis, } \\
\text { Escherichia coli, } \\
\text { Group D streptococcus, } \\
\text { Klebisella pneumoniae }\end{array}$ & SAH, craniotomy, VPS & $\begin{array}{l}\text { Fever, altered } \\
\text { consciousness, } \\
\text { hydrocephalus, } \\
\text { leukocytosis }\end{array}$ & $\begin{array}{l}\text { EVD (removal } \\
\text { of VPS) }\end{array}$ & $\begin{array}{l}\text { VA, ROC, } \\
\text { MET }\end{array}$ & Yes \\
\hline 14 & $58 / \mathrm{F}$ & $\begin{array}{l}\text { Acinetobacter lwoffii, } \\
\text { Staphylococcus } \\
\text { epidermidis }\end{array}$ & SAH, EVD & $\begin{array}{l}\text { Fever, altered } \\
\text { consciousness, } \\
\text { hydrocephalus }\end{array}$ & $\begin{array}{l}\text { EVD (removal } \\
\text { of old EVD) }\end{array}$ & VA, ROC & Yes \\
\hline 15 & $72 / \mathrm{M}$ & $\begin{array}{l}\text { Citrobacter diversus, } \\
\text { Pseudomonas aeruginosa }\end{array}$ & SICH, VPS & $\begin{array}{l}\text { Seizure, } \\
\text { hydrocephalus, } \\
\text { leukocytosis }\end{array}$ & $\begin{array}{l}\text { EVD (removal } \\
\text { of VPS) }\end{array}$ & MAX & No \\
\hline 16 & $20 / \mathrm{M}$ & $\begin{array}{l}\text { Klebsiella pneumoniae, } \\
\text { Pseudomonas } \\
\text { aeruginosa, Proteus } \\
\text { mirabilis }\end{array}$ & TICH, EVD & $\begin{array}{l}\text { Fever, altered } \\
\text { consciousness, } \\
\text { hydrocephalus, CSF } \\
\text { leak, leukocytosis }\end{array}$ & $\begin{array}{l}\text { EVD (removal } \\
\text { of old EVD) }\end{array}$ & VA, MEP & No \\
\hline 17 & $68 / \mathrm{M}$ & $\begin{array}{l}\text { Acinetobacter junnii, } \\
\text { Enterococcus faecalis }\end{array}$ & SICH, craniotomy, EVD & Fever, hydrocephalus & Removal of EVD & VA, CAZ & Yes \\
\hline
\end{tabular}


Table 1: Contd...

\begin{tabular}{|c|c|c|c|c|c|c|c|}
\hline Patient & Age/gender & Pathogens & Underlying condition & Clinical presentations & Management & Antibiotics & Survived \\
\hline 18 & $42 / \mathrm{F}$ & $\begin{array}{l}\text { Pseudomonas } \\
\text { aeruginosa, Shewanella } \\
\text { putrefaciens }\end{array}$ & SICH, EVD & $\begin{array}{l}\text { Fever, altered } \\
\text { consciousness, } \\
\text { leukocytosis }\end{array}$ & $\begin{array}{l}\text { EVD (removal } \\
\text { of old EVD) }\end{array}$ & MAX & Yes \\
\hline
\end{tabular}

Abbreviations: F: Female; M: Male; DM: Diabetes mellitus; SAH: Subarachnoid hemorrhage; SICH: Spontaneous intracerebral hemorrhage; RHD: Rheumatic heart disease; TICH: Traumatic intracranial hemorrhage; ROC: Ceftriaxone; CIP: Ciprofloxacin; VA: Vancomycin; CAZ: Ceftazidime; MET: Metronidazole; LZD: Linezolid; MEP: Meropenem; MAX: Cefepime; *: From anaerobic culture

spontaneous $\mathrm{ICH}+\mathrm{s} / \mathrm{p}$ craniotomy $+\mathrm{VP}$ shunt in one case (Case 13), spontaneous ICH + s/p VP shunt in one case (Case 15), traumatic ICH $+\mathrm{s} / \mathrm{p}$ craniotomy $+\mathrm{VP}$ shunt in two cases (cases 7 and 10), traumatic ICH $+\mathrm{s} / \mathrm{p}$ craniectomy + VP shunt + craniotomy in one case (Case 4), traumatic ICH + craniectomy + cranioplasty + EVD in one case (Case 11), traumatic ICH + s/p EVD in one case (Case 16), acute cerebral infarction (ACI) $+\mathrm{s} / \mathrm{p}$ craniectomy in one case (Case 1), ACI + EVD in one case (Case 6), ACI + EVD in one case (Case 9), and hydrocephalus + VP shunt in one case (Case 8). Among these 18 cases, diabetes mellitus (DM) was found in four cases (cases 1, 3, 8, and 9). Totally, 45 implicated bacterial strains were found in these 18 post-NS ABM cases with mixed infection [Tables 1 and 2], and they were $34 \mathrm{Gram}$-negative [Gm(-)] strains (four anaerobic strains included) and 11 Gram-positive $[\mathrm{Gm}(+)]$ strains. Of the implicated Gm(-) pathogens, Escherichia coli (6) was the most common, followed by Acinetobacter spp. (5) and Pseudomonas spp. (5), Klebsiella spp. (4), Bacteroides spp. (3), Brevundimonas diminuta (2), Citrobacter spp. (2), Elizabethkingia meningoseptica (1), Alcaligenes faecalis (1), Comamonas acidovorans (1), Shewanella putrefaciens (1), Enterobacter cloacae (1), Proteus mirabilis (1), and Provetella spp. (1). The 11 implicated $\mathrm{Gm}(+)$ strains included Enterococcus spp. (3), Staphylococcus epidermidis (2), Staphylococcus aureus (1), Staphylococcus chromogenes (1), unclassified coagulase-negative staphylococci (1), viridian streptococcus (1), Streptococcus pneumoniae (1), and Group D beta-streptococcus (1). The antibiogram of these 45 implicated strains is listed in Table 3 . The implicated bacterial strains of the other 133 monomicrobial $\mathrm{ABM}$ are also shown in Table 2, and they included $68 \mathrm{Gm}(-)$ strains and $65 \mathrm{Gm}(+)$ strains. Of the $68 \mathrm{Gm}(-)$ strains, Acinetobacter baumannii (18) was the most common, followed by Klebsiella pneumoniae (11) and Pseudomonas aeruginosa (9). Of the $65 \mathrm{Gm}(+)$ strains, staphylococcal spp. (45) was the most common, followed by Enterococcus spp. (8) and Streptococcus spp. (7).

As shown in Table 1, the major antibiotics used for the treatment of these 18 cases of ABM with mixed infection included vancomycin, linezolid, ceftazidime, cefepime, meropenem, and metronidazole, and the main NS procedures that had been undertaken for these 18 post-NS ABM cases with mixed infection included creating new EVD with removal of old VP shunt in five cases (cases 2, 4, 10, 13, and 15), creating new EVD with removal of old EVD in five cases (cases 3,11,14,16, and 18), removal of EVD in five cases (cases 5, 6, 9, 12, and 17), removal of VP shunt in two cases (cases 7 and 8), and craniectomy in Case 1. The therapeutic result showed 12 cases (cases 2, 4-6, 8-11, $13,14,17$, and 18) survived and 6 cases died (cases 1, 3, $7,12,15$, and 16). Of the 12 survived cases, 6 cases had clear consciousness (bed-ridden in Case 6 and independent walking in cases 2, 4, 5, 8, and 13) and the other 6 cases were in vegetative state. A clinical comparison between the survived and expired cases of post-NS ABM is shown in Table 4 and no definite prognostic factor was found. In this study, as shown in Table 5, we also compared the clinical and laboratory characteristics between the ABM with mixed infection and monomicrobial infection, and the result showed that those with monomicrobial infection had a higher CSF white blood cell count $(p=0.014)$.

\section{DISCUSSION}

In a large-scale study of $\mathrm{ABM},{ }^{[2]}$ mixed infection was found in $7 \%$ of the patients with nosocomial infection and most of the cases were related to a post-NS state. In this study, $10.6 \%$ (18/170) of the post-NS ABM cases had a mixed infection state. Compared with the results of our previous and other large-scale studies of ABM,,$^{[1,2,4,5,19-23]}$ this figure of incidence of mixed infection is relatively higher and can be related to the increased number of post-NS $\mathrm{ABM}$ cases in our hospital. ${ }^{[1]}$ All these may further confirm the finding of previous reports ${ }^{[1,2,4,5,24]}$ which showed that presence of post-NS condition is the most important preceding event for the development of mixed infection in ABM. As shown in Tables 1, 4, and 5, the main clinical and laboratory presentations of these 18 cases of ABM with mixed infection were fever $(88.9 \%, 16 / 18)$, altered consciousness $(38.9 \%, 7 / 18)$, and seizure $(27.8 \%, 5 / 18)$, hydrocephalus in $66.7 \%(12 / 18)$ of the neuroimage study, and $77.8 \%(14 / 18)$ had a peripheral leukocytosis; but all these presentations are not unique, and can be found in other groups of ABM. ${ }^{[1,2,4,5,24]}$ In this study, as shown in Table 5, the difference between the post-NS ABM with monomicrobial and mixed infection was not distinct although those with monomicrobial infection had a higher CSF white blood cell

Biomed J Vol. 36 No. 6

November - December 2013 
Table 2: The implicated bacterial pathogens of the enrolled post-neurosurgical adult bacterial meningitis cases

\begin{tabular}{|c|c|c|}
\hline Pathogens & $\begin{array}{c}\text { Mixed } \\
\text { infection } \\
(n=45)\end{array}$ & $\begin{array}{c}\text { Monomicrobial } \\
\text { infection } \\
(n=133)\end{array}$ \\
\hline Gram negative & (34) & $(68)$ \\
\hline Escherichia coli & 6 & 5 \\
\hline Pseudomonas aeruginosa & 5 & 9 \\
\hline Klebsiella pneumoniae & 3 & 11 \\
\hline Acinetobacter junnii & 2 & \\
\hline Brevundimonas diminuta & 2 & \\
\hline Acinetobacter baumannii & 1 & 18 \\
\hline Enterobacter cloacae & 1 & 8 \\
\hline Acinetobacter lwoffii & 1 & 2 \\
\hline Klebsiella oxytoca & 1 & \\
\hline Proteus mirabilis & 1 & \\
\hline Acinetobacter spp. & 1 & 1 \\
\hline Elizabethkingia meningoseptica & 1 & 1 \\
\hline Citrobacter freundii & 1 & \\
\hline Alcaligenes faecalis & 1 & \\
\hline Comamonas acidovorans & 1 & \\
\hline Shewanella putrefaciens & 1 & \\
\hline Serratia marcences & & 3 \\
\hline Citrobacter diversus & 1 & 1 \\
\hline \multicolumn{3}{|l|}{ Neisseria meningitides } \\
\hline Enterobacter aerogenes & & 3 \\
\hline Bacteroides distonis & 1 & \\
\hline Bacteroides fragilis & 1 & \\
\hline Bacteroides uniformis & 1 & \\
\hline Provetella spp. & 1 & \\
\hline Others & & $6^{*}$ \\
\hline Gram positive & (11) & $(65)$ \\
\hline Coagulase-negative staphylococci & 4 & 23 \\
\hline Enterococcus spp. & 2 & 2 \\
\hline Staphylococcus aureus & 1 & 22 \\
\hline Enterococcus faecalis & 1 & 6 \\
\hline Viridian streptococci & 1 & 3 \\
\hline Streptococcus pneumoniae & 1 & 3 \\
\hline Group D beta-streptococci & 1 & \\
\hline Others & & $6 \dagger$ \\
\hline
\end{tabular}

*: Pseudomonas mendocina (1), Pseudomonas putida (1), Pseudomonas stutzeri (1), Stenotrophomonas maltophilia (1), Salmonella enterica group D (1), unclassified glucose non-fermenting group (1); †: Listeria monocytogenes (1), Micrococcus (1), Corynebacterium (3), Group A beta-streptococci (1)

count. Therefore, the presence of mixed infection in post-NS ABM can only be confirmed by a positive CSF culture and a high suspicion is needed for its identification, especially in those with a preceding post-NS state.

Of the implicated bacterial pathogens of the present 18 post-NS ABM patients with mixed infection, Gm(-) pathogens were the most common $(76 \%, 34 / 45)$, followed by $\mathrm{Gm}(+)$ pathogens $(24 \%, 11 / 45)$. The condition of $\mathrm{Gm}(+)$ strains outnumbered by Gm(-) strains as the implicated pathogens of ABM has been noted as an important epidemiolologic change in Taiwan. ${ }^{[1]}$ Previous studies ${ }^{[1,10,25,26]}$ have shown that the high incidence of Gm(-) strains as the implicated pathogens of ABM is noted especially in those with a preceding post-NS state. This relatively higher number of $\mathrm{Gm}(-)$ pathogen was also noted in a previous study of ABM with mixed infection reported by Chang et al., in 2000, ${ }^{[4]}$ in which Enterobacter spp., Es. coli, and Klebsiella spp. were the common Gm(-) pathogens. In present study, Es. coli, Pseudomonas spp., Acinetobacter spp., and Klebsiella spp. were the most common. This change of relative frequency of implicated Gm(-) pathogens should deserve special mention because a development of resistance to the commonly used $3^{\text {rd }}$ or $4^{\text {th }}$ generation cephalosporin in the treatment of $\mathrm{ABM}$ or the development of multi-drug resistance strains has been noted in these main $\mathrm{Gm}(-)$ pathogens. ${ }^{[27-30]}$ This development may cause a great difficulty in the choice of appropriate antibiotics and result in a therapeutic challenge of this specific of ABM.

Meanwhile, except En. cloacae and P. mirabilis, the other implicated $\mathrm{Gm}(-)$ pathogens including $B$. diminuta, E. meningoseptica, A. faecalis, C. acidovorans, and S. putrefaciens are all uncommon pathogens of $\mathrm{ABM}^{[1,2]}$ and were not found in our previous study of ABM with mixed infection. ${ }^{[4]}$ Among these uncommon Gm(-) pathogens, B. diminuta and $C$. acidovorans belong to Pseudomonas rRNA homology groups II and III, respectively, ${ }^{[31,32]}$ while E. meningoseptica, A. faecalis, and S. putrefaciens belong to non-fermentative $\mathrm{Gm}(-)$ rods. ${ }^{[33-35]}$ These uncommon strains are usually becoming pathogenic in specific groups of patients, especially in those with malignancy and other immunocompromised states. The treatment of these uncommon $\mathrm{Gm}(-)$ pathogens associated bacterial meningitis also needs special consideration because most of them are not susceptible to the common antibiotics, such as $3^{\text {rd }}$ generation cephalosporins, used in the treatment of ABM. ${ }^{[31-36]}$

$\mathrm{Gm}(+)$ pathogens including Staphylococcus, Streptococcus, and Enterococcus spp. accounted for 24\% (11/45) of the implicated pathogens of this study. These $\mathrm{Gm}(+)$ strains are also common pathogens of ABM in Taiwan,,$^{[1,17,37,38]}$ and their infections are usually associated with $\mathrm{ABM}$ patients with a preceding post-NS state. All these $\mathrm{Gm}(+)$ strains found in post-NS ABM usually have a high incidence of antimicrobial resistance, and this finding was also noted in this study [Table 3]. For Gm(+) pathogen-related ABM treatment, vancomycin or linezolid is usually the drug of choice. In our hospital, vancomycin is chosen as the initial empiric antibiotic used in the treatment of adult patients with highly suspected acute bacterial meningitis; therefore, so far, the choice of appropriate antibiotic in ABM related to these $\mathrm{Gm}(+)$ pathogens is usually not a therapeutic 
Table 3: Antibiogram of the 18 post-neurosurgical adult bacterial meningitis cases with mixed infection

\begin{tabular}{|c|c|c|c|c|c|c|c|c|c|c|c|}
\hline Cases & Pathogens & ROC & CAZ & MAX & MEP & CIP & UNA & $\mathrm{PCN}$ & OX & VA & MET \\
\hline \multirow[t]{2}{*}{1} & Escherichia coli & $\mathrm{S}$ & $\mathrm{S}$ & $\mathrm{S}$ & $\mathrm{S}$ & $\mathrm{S}$ & & & & & \\
\hline & Elizabethkingia meningoseptica & & $\mathrm{R}$ & $\mathrm{R}$ & $\mathrm{R}$ & $\mathrm{S}$ & & & & & \\
\hline \multirow[t]{6}{*}{2} & Escherichia coli & $\mathrm{S}$ & $\mathrm{S}$ & $\mathrm{S}$ & $\mathrm{S}$ & & & & & & \\
\hline & Enterococcus & & & & & & & $\mathrm{S}$ & & $\mathrm{S}$ & \\
\hline & Klebsiella oxytoica & $\mathrm{S}$ & $\mathrm{S}$ & $\mathrm{S}$ & $\mathrm{S}$ & & & & & & \\
\hline & Pseudomonas aeruginosa & & $\mathrm{S}$ & $S$ & $\mathrm{~S}$ & $\mathrm{~S}$ & & & & & \\
\hline & Bacteroides distaonis & & & & & & & $\mathrm{R}$ & & & $\mathrm{S}$ \\
\hline & Bacteroides uniformis & & & & & & & $\mathrm{R}$ & & & S \\
\hline \multirow[t]{2}{*}{3} & Escherichia coli & $\mathrm{S}$ & $\mathrm{S}$ & $\mathrm{S}$ & $\mathrm{S}$ & $\mathrm{S}$ & & & & & \\
\hline & Enterococcus & & & & & & & $\mathrm{S}$ & & $\mathrm{S}$ & \\
\hline \multirow[t]{2}{*}{4} & Staphylococcus chromogenes & & & & & & & & $\mathrm{R}$ & $\mathrm{S}$ & \\
\hline & $\begin{array}{l}\text { Coagulase-negative } \\
\text { staphylococci }\end{array}$ & & & & & & & & $\mathrm{R}$ & $\mathrm{S}$ & \\
\hline \multirow[t]{2}{*}{5} & Citrobacter freundii & & $\mathrm{S}$ & $\mathrm{S}$ & $\mathrm{S}$ & $\mathrm{S}$ & & & & & \\
\hline & Escherichia coli & $\mathrm{R}$ & $\mathrm{R}$ & $\mathrm{R}$ & $\mathrm{S}$ & $\mathrm{R}$ & & & & & \\
\hline \multirow[t]{2}{*}{6} & Enterobacter cloacae & $\mathrm{S}$ & $\mathrm{S}$ & $S$ & $\mathrm{~S}$ & $\mathrm{~S}$ & & & & & \\
\hline & Klebsiella pneumoniae & $\mathrm{S}$ & $\mathrm{S}$ & S & $\mathrm{S}$ & $\mathrm{S}$ & & & & & \\
\hline \multirow[t]{2}{*}{7} & Staphylococcus aureus & & & & & & & & $\mathrm{R}$ & $\mathrm{S}$ & \\
\hline & Prevotella spp. & & & & & & & & $\mathrm{R}$ & & $\mathrm{S}$ \\
\hline \multirow[t]{2}{*}{8} & Acinetobacter junnii & & $\mathrm{S}$ & $S$ & $\mathrm{~S}$ & $\mathrm{~S}$ & & & & & \\
\hline & Staphylococcus epidermidis & & & & & & & & $\mathrm{R}$ & $\mathrm{S}$ & \\
\hline \multirow[t]{3}{*}{9} & Acaligenes faecalis & $\mathrm{S}$ & $\mathrm{R}$ & $\mathrm{I}$ & $\mathrm{S}$ & $\mathrm{R}$ & & & & & \\
\hline & Brevundimonas diminuta & & $\mathrm{R}$ & $\mathrm{R}$ & $\mathrm{S}$ & $\mathrm{R}$ & & & & & \\
\hline & Comamonas acidovorans & $\mathrm{S}$ & $\mathrm{S}$ & $S$ & $\mathrm{~S}$ & $\mathrm{~S}$ & & & & & \\
\hline \multirow[t]{3}{*}{10} & Escherichia coli & $\mathrm{S}$ & $\mathrm{S}$ & $S$ & $\mathrm{~S}$ & $\mathrm{~S}$ & & & & & \\
\hline & Pseudomonas aeruginosa & & $\mathrm{S}$ & $S$ & $\mathrm{~S}$ & $\mathrm{~S}$ & & & & & \\
\hline & Streptococcus pneumoniae & & & & & & & $\mathrm{S}$ & & $\mathrm{S}$ & \\
\hline \multirow[t]{2}{*}{11} & Acinetobacter baumannii & & I & $\mathrm{R}$ & $\mathrm{R}$ & $\mathrm{R}$ & $\mathrm{S}$ & & & & \\
\hline & Viridian streptococci & & & & & & & I & & $\mathrm{S}$ & \\
\hline \multirow[t]{2}{*}{12} & Acinetobacter spp. & & $\mathrm{R}$ & S & $\mathrm{S}$ & & & & & & \\
\hline & Brevundimonas diminuta & I & $\mathrm{R}$ & I & $\mathrm{S}$ & & & & & & \\
\hline \multirow[t]{4}{*}{13} & Bacteroides fragilis & & & & & & & & & & S \\
\hline & Escherichia coli & $\mathrm{S}$ & $\mathrm{S}$ & $\mathrm{S}$ & $\mathrm{S}$ & $\mathrm{S}$ & & & & & \\
\hline & Group D streptococci & & & & & & & $\mathrm{S}$ & & $\mathrm{S}$ & \\
\hline & Klebseilla pneumoniae & $\mathrm{S}$ & $\mathrm{S}$ & $\mathrm{S}$ & $\mathrm{S}$ & $\mathrm{S}$ & & & & & \\
\hline \multirow[t]{2}{*}{14} & Acinetobacter lwoffii & & $\mathrm{S}$ & & $\mathrm{S}$ & $\mathrm{S}$ & & & & & \\
\hline & Staphylococcus epidermidis & & & & & & & & $\mathrm{R}$ & $\mathrm{S}$ & \\
\hline \multirow[t]{2}{*}{15} & Citrobacter diversus & $\mathrm{R}$ & $\mathrm{S}$ & S & $\mathrm{S}$ & & & & & & \\
\hline & Pseudomonas aeruginosa & & $\mathrm{S}$ & S & $\mathrm{S}$ & & & & & & \\
\hline \multirow[t]{5}{*}{16} & Klebsiella pneumoniae & $\mathrm{S}$ & $\mathrm{S}$ & S & $\mathrm{S}$ & $\mathrm{S}$ & & & & & \\
\hline & Pseudomonas aeruginosa & & $\mathrm{S}$ & S & $\mathrm{S}$ & $\mathrm{R}$ & & & & & \\
\hline & & & $\mathrm{S}$ & I & $\mathrm{R}$ & $\mathrm{R}$ & & & & & \\
\hline & & & $\mathrm{R}$ & $\mathrm{R}$ & $\mathrm{R}$ & $\mathrm{R}$ & & & & & \\
\hline & Proteus mirabilis & & $\mathrm{R}$ & $\mathrm{S}$ & $\mathrm{S}$ & & & & & & \\
\hline \multirow[t]{2}{*}{17} & Acinetobacter junnii & & $\mathrm{S}$ & & $\mathrm{S}$ & & & & & & \\
\hline & Enterococcus faecalis & & & & & & & $\mathrm{S}$ & & $\mathrm{S}$ & \\
\hline \multirow[t]{2}{*}{18} & Pseudomonas aeruginosa & & $\mathrm{S}$ & & $\mathrm{S}$ & & & & & & \\
\hline & Shewanella putrefaciens & & $\mathrm{S}$ & & $\mathrm{S}$ & & & & & & \\
\hline
\end{tabular}

Abbreviations: ROC: Ceftriaxone; CAZ: Ceftazidime; MAX: Cefepime; MEP: Meropenem; CIP: Ciprofloxacin; UNA: Ampicillin/sulbactam; PCN: Penicillin; OX: Oxacillin; VA: Vancomycin; MET: Metronidazole; S: Susceptible; I: Intermediate; R: Resistant

Biomed J Vol. 36 No. 6

November - December 2013 
Table 4: Prognostic factors of the 18 adult post-neurosurgical bacterial meningitis patients with mixed infection

\begin{tabular}{|c|c|c|c|}
\hline & $\begin{array}{c}\text { Expired } \\
(n=6)\end{array}$ & $\begin{array}{l}\text { Survived } \\
(n=12)\end{array}$ & $p$ \\
\hline \multicolumn{4}{|l|}{ Age (years) } \\
\hline Median (range) & $58(20-72)$ & $54(30-77)$ & 0.682 \\
\hline \multicolumn{4}{|l|}{ Gender } \\
\hline Male & 4 & 7 & 1.000 \\
\hline Female & 2 & 5 & \\
\hline \multicolumn{4}{|l|}{ Underlying condition } \\
\hline Diabetes mellitus & 2 & 2 & 0.569 \\
\hline Community acquired & 1 & 2 & 1.000 \\
\hline \multicolumn{4}{|l|}{ Clinical presentation } \\
\hline Fever & 5 & 11 & 1.000 \\
\hline Altered consciousness & 2 & 5 & 1.000 \\
\hline Seizure & 3 & 2 & 0.268 \\
\hline Shock & 1 & 0 & 0.333 \\
\hline Hydrocephalus & 5 & 7 & 0.600 \\
\hline Cerebrospinal fluid leak & 1 & 0 & 0.333 \\
\hline Brain abscess & 1 & 1 & 1.000 \\
\hline Positive blood culture & 0 & 2 & 0.529 \\
\hline Leukocytosis & 6 & 8 & 0.245 \\
\hline \multicolumn{4}{|l|}{$\begin{array}{l}\text { Cerebrospinal fluid study, } \\
\text { IQR }\end{array}$} \\
\hline White cell count $\left(10^{9} / \mathrm{L}\right)$ & $0.12(0.07,2.27)$ & $0.04(0.01,0.17)$ & 0.093 \\
\hline Glucose (mmol/L) & $3.74(2.34,6.89)$ & $3.03(1.38,4.05)$ & 0.364 \\
\hline Protein (g/L) & $0.56(0.43,23.20)$ & $0.92(0.52,1.86)$ & 0.438 \\
\hline Lactate (mmol/L) & $4.32(1.03,4.26)$ & $2.31(3.86,5.29)$ & 0.933 \\
\hline
\end{tabular}

Abbreviations: IQR: Inter-quartile range (25 percentile, 75 percentile)

problem. In this study, anaerobic strains Bacteroides spp. and Prevotella spp. were also noted, accounting for $8.9 \%$ (4/45) of the implicated bacterial pathogens of post-NS ABM with mixed infection. These anaerobic pathogens are uncommonly found in $\mathrm{ABM},{ }^{[1,4]}$ and usually occur in specific groups of patients. ${ }^{[39-44]}$ However, their emergence as the pathogenic strains of post-NS ABM deserves special mention because they need different antimicrobial agents such as metronidazole, carbapenems, and a combination of penicillin and beta-lactamase inhibitor for therapeutic consideration. ${ }^{[40-45]}$

Bacterial meningitis is a serious complication of Post-NS state, and these concomitant situations are ensured a high morbidity and mortality. ${ }^{[10,14]}$ The high mortality rate $(36 / 151,23.8 \%)$ [Table 5] of this specific group of ABM cases was also noted in this study, in which those with a mixed infection had a higher rate $(33.3 \%$, $6 / 18)$ than those with a monomicrobial infection $(22.6 \%$, 30/133), although this difference did not reach a statistical significance. As shown in Table 1, cases 2, 7, and 13 had anaerobic pathogen infection, but none of them had brain abscess. Case 7 died in the therapeutic course; i.e., in present study, the mortality rate $(1 / 3,33.3 \%)$ of patients
Table 5: Clinical and laboratory comparison between the adult post-neurosurgical bacterial meningitis patients with mixed infection and with monomicrobial infection

\begin{tabular}{|c|c|c|c|}
\hline & $\begin{array}{c}\text { Mixed } \\
\text { infection } \\
(n=18)\end{array}$ & $\begin{array}{l}\text { Monomicrobial } \\
\text { infection } \\
(n=133)\end{array}$ & $p$ \\
\hline \multicolumn{4}{|l|}{ Age (years) } \\
\hline Median (range) & $57.5(20-77)$ & $56(18-78)$ & 0.787 \\
\hline \multicolumn{4}{|l|}{ Gender } \\
\hline Male & 11 & 93 & 0.431 \\
\hline Female & 7 & 40 & \\
\hline \multicolumn{4}{|l|}{ Underlying condition } \\
\hline Diabetes mellitus & 4 & 21 & 0.502 \\
\hline Liver cirrhosis & 0 & 2 & 1.000 \\
\hline Alcoholism & 0 & 5 & 1.000 \\
\hline End-stage renal diseases & 0 & 1 & 1.000 \\
\hline Malignancy & 0 & 21 & 0.078 \\
\hline Community acquired & 3 & 25 & 1.000 \\
\hline \multicolumn{4}{|l|}{ Clinical presentation } \\
\hline Fever & 16 & 108 & 0.532 \\
\hline Altered consciousness & 7 & 59 & 0.802 \\
\hline Seizure & 5 & 30 & 0.567 \\
\hline Shock & 1 & 12 & 1.000 \\
\hline Hydrocephalus & 12 & 60 & 0.130 \\
\hline Cerebrospinal fluid leak & 1 & 10 & 1.000 \\
\hline Intracranial abscess & 2 & 16 & 1.000 \\
\hline Positive blood culture & 2 & 19 & 1.000 \\
\hline Leukocytosis & 14 & 83 & 0.295 \\
\hline \multicolumn{4}{|c|}{ Cerebrospinal fluid study, IQR } \\
\hline White cell count $\left(10^{9} / \mathrm{L}\right)$ & $\begin{array}{c}0.067 \\
(0.034,0.173)\end{array}$ & $\begin{array}{c}0.335 \\
(0.085,1.589)\end{array}$ & $0.014 *$ \\
\hline Glucose (mmol/L) & $\begin{array}{c}3.19 \\
(2.17,4.51)\end{array}$ & $\begin{array}{c}2.86 \\
(0.82,4.13)\end{array}$ & 0.392 \\
\hline Protein $(\mathrm{g} / \mathrm{L})$ & $\begin{array}{c}0.68 \\
(0.50,1.55)\end{array}$ & $\begin{array}{c}1.41 \\
(0.64,2.99)\end{array}$ & 0.103 \\
\hline Lactate $(\mathrm{mmol} / \mathrm{L})$ & $\begin{array}{c}4.61 \\
(2.90,5.88)\end{array}$ & $\begin{array}{c}6.27 \\
(4.01,11.67)\end{array}$ & 0.077 \\
\hline \multicolumn{4}{|l|}{ Prognosis } \\
\hline Survived & 12 & 103 & 0.376 \\
\hline Expired & 6 & 30 & \\
\hline
\end{tabular}

Abbreviations: IQR: Inter-quartile range ( 25 percentile, 75 percentile); *: Mann-Whitney U test $(p<0.05)$

with anaerobic pathogen infection was not higher than that $(6 / 18,33.3 \%)$ of the overall cases. As also shown in Table 4, no significant prognostic factor was found between the fatal and non-fatal cases of post-NS ABM with mixed infection. In a large-scale study of risk factors and prognostic indicators of bacterial meningitis in a cohort of 3580 post-NS patients reported by Federico et al., the mortality rate was $8 \%$ and the predictors of mortality included low CSF glucose concentration, increased value of the Acute Physiology and Chronic Health Evaluation (APACHE) III score, and Gm(-) pathogen infection. ${ }^{[46]}$ In this study, 
as shown in Table 1, four (cases 1, 12, 15, and 16) of the eight $\mathrm{ABM}$ cases with a pure $\mathrm{Gm}(-)$ pathogen-related infection died (50\%), while only two (cases 3 and 7) of the other $10 \mathrm{ABM}$ cases with a mixed $\mathrm{Gm}(-)$ and $\mathrm{Gm}(+)$ pathogen-related mixed infection died (20\%); but the case number of different pathogen combinations is too small to draw a prognostic conclusion. Many factors including primary brain pathology, delayed diagnosis, a delay in using appropriate antibiotics, and the serious complications of bacterial meningitis may influence the therapeutic result of post-NS ABM, ${ }^{[1,2,6,7,10,14]}$ and the reported therapeutic results (including the mortality rate) varied greatly between different study reports of adult nosocomial and/or post-NS ABM. $\cdot^{[1,5,10,14,16,24-26,46]}$ Clinically, it is difficult to compare the mortality rates reported by the different studies of ABM because different patient groups (e.g., difference in age and difference in implicated pathogens) were enrolled and different therapeutic regimens were used. ${ }^{[1,5,10,14,16,24-26,46]}$ Although the mortality rate shown in the report of Federico et al. . ${ }^{[4]}$ was lower than that of the present study, it is difficult to make a comparative analysis of the mortality rates because of the following: (1) the difference in enrolled age groups and (2) the difference in the prevalence of implicated pathogens $[\mathrm{Gm}(+)$ vs. $\mathrm{Gm}(-)]$. In addition, mixed infection was not the main issue of the study reported by Federico et al. ${ }^{[46]}$ In this study of post-NS ABM with mixed infection, the presence of multiple pathogens-related infection and their high incidence of antibiotic resistance may make the situation more complicated. Nevertheless, further large-scale study is needed for a better delineation of the prognostic factors of this specific ABM syndrome.

In conclusion, mixed infection is not uncommon in post-NS ABM (10.6\%) and the mortality rate $(33.3 \%)$ is high in this specific ABM syndrome. Seventy-six percent of the implicated bacterial pathogens of post-NS ABM with mixed infection belonged to $\mathrm{Gm}(-)$ strains, while the other $24 \%$ belonged to $\mathrm{Gm}(+)$ strains. Among the implicated $\mathrm{Gm}(-)$ pathogens, uncommon $\mathrm{Gm}(-)$ strains for $\mathrm{ABM}$ and anaerobic strains have appeared and their presence needs special consideration in the choice of appropriate antimicrobial agents for treatment. The clinical and laboratory features of $\mathrm{ABM}$ with mixed infection are not unique; its diagnosis can only be made by a positive CSF culture and a high suspicion of this specific infectious syndrome, especially in those with a preceding post-NS state, is important for its early identification.

\section{REFERENCES}

1. Chang WN, Lu CH, Huang CR, Tsai NW, Chuang YC, Chang CC, et al. Changing epidemiology of adult bacterial meningitis in southern Taiwan: A hospital-based study. Infection 2008;36:15-22.

2. Durand M, Calderwood SB, Weber DJ, Miller SI, Southwick FS,
Caviness VS Jr, et al. Acute bacterial meningitis in adults: A review of 493 episodes. N Engl J Med 1993;328:21-8.

3. Ruef C. Bacterial meningitis - problems on many fronts. Infection 2000;28:1-2.

4. Chang WN, Lu CH, Huang CR, Chuang YC. Mixed infection in adult bacterial meningitis. Infection 2000;28:8-12.

5. Downs NJ, Hodges GR. Mixed bacterial meningitis. Rev Infect Dis 1987;9:693-703

6. Ziai WC, Lewin III JJ. Update in the diagnosis and management of central nervous system infections. Neuro Clin North Am 2008;26:427-68.

7. Fitch MT, van de Beek D. Emergency diagnosis and treatment of adult meningitis. Lancet Infect Dis 2007;7:191-200.

8. Lai WA, Chen SF, Tsai NW, Chang CC, Chang WN, Lu CH, et al. Clinical characteristics and prognosis of acute bacterial meningitis in elderly patients over 65: A hospital-based study. BMC Geriatr 2011;11:91.

9. Tsai MH, Lu CH, Huang CR, Chuang YC, Tsai NW, Tsai HH, et al. Bacterial meningitis in young adults in Southern Taiwan: Clinical characteristics and therapeutic outcomes. Infection 2006;34:2-8.

10. Wang KW, Chang WN, Huang CR, Tsai NW, Tsui HW, Wang HC, et al. Post-neurosurgical nosocomial bacterial meningitis in adults: Microbiology, clinical features and outcomes. J Clin Neurosci 2005; $12: 647-50$

11. Cheng BC, Chang WN, $\mathrm{Lu} \mathrm{CH}$, Chen JB, Chang CS, Lee $\mathrm{CH}$, et al. Bacterial meningitis in hemodialyzed patients. J Nephrol 2004; 17:236-41.

12. Chang WN, Lu CH, Wu JJ, Lei CB, Huang CR. Community-acquired spontaneous Klebsiella pneumoniae meningitis in adult cirrhotic patients with and without diabetes. Eur J Microbiol Infect Dis 2003;22:271-3.

13. Huang CR, Lu CH, Chang HW, Lee PY, Lin MW, Chang WN. Community-acquired spontaneous bacterial meningitis in adult diabetic patients: An analysis of clinical characteristics and prognostic factors. Infection 2002;30:346-50.

14. Chang CJ, Ye JJ, Yang CC, Huang PY, Chiang PC, Lee MH. Influence of third-generation cephalosporin resistance on adult in-hospital mortality from post-neurosurgical bacterial meningitis. J Microbiol Immunol Infect 2010;43:301-9.

15. Huang CR, Chen SF, Lu CH, Chuang YC, Tsai NW, Chang CC, et al. Clinical characteristics and therapeutic outcome of nosocomial superinfection in adult bacterial meningitis. BMC Infect 2011;11:133.

16. Tängdén T, Enblad P, Ullberg M, Sjölin J. Neurosurgical gram-negative bacillary ventriculitis and meningitis: A retrospective study evaluating the efficacy of intraventricular gentamicin therapy in 31 consecutive cases. Clin Infect Dis 2011;52:1310-6.

17. Chang WN, Lu CH, Huang CR, Chuang YC, Tsai NW, Chen SF, et al. Epidemiology of adult staphylococcal meningitis in southern Taiwan: A clinical comparison of Staphylococcus aureus infection and coagulase-negative staphylococcal infection. Jpn J Infect Dis 2007;60:262-6

18. Peña C, Suarez C, Tubau F, Juan C, Moya B, Dominguez MA, et al. Nosocomial outbreak of non-cefepime-susceptible ceftazidime susceptible Pseudomonas aeruginosa strain overexpression MexXY-OprM and producing an integron-borne PSE-1 beta-lactamase. J Clin Microbiol 2009;47:2381-7.

19. Sigurardóttir B, Bjönsson OM, Jónsdóttir KE, Erlendsdóttir H,

Biomed J Vol. 36 No. 6

November - December 2013 
Gudmundsson S. Acute bacterial meningitis in adults: A 20-year overview. Arch Intern Med 1997;157:425-30.

20. Hoşoğlu S, Ayaz C, Geyik MF, Kökoglu OF, Ozen A. Acut bacterial meningitis in adults: Analysis of 218 episodes. Lr J Med Sci 1997; 166:231-4.

21. Kyaw MH, Christie P, Jones IG, Campbell H. The changing epidemiology of bacterial meningitis and invasive non-meningitic bacterial disease in scotland during the period 1983-99. Scand J Infect Dis 2002;34:289-98.

22. Chan YC, Wilder-Smith A, Ong BK, Kumarasinghe G, wilder-Smith E. Adult community acquired bacterial meningitis in a Singaporean teaching hospital: A seven-year overview (1993-2000). Singapore Med J 2002;43:632-6.

23. Khawnnimit B, Chayakul P, Geater A. Acute bacterial meningitis in adults: A 20 year review. Southeast Asian J Trop Med Public Health 2004;35:886-92.

24. Brook I, Johnson N, Overturf GD, Wilkins J. Mixed bacterial meningitis: A complication of ventroculo- and lumboperitoneal shunts. J Neurosurg 1977;47:961-4.

25. O'Neill E, Humphreys H, Phillips J, Smyth EG. Third-generation cephalospori resistance among Gram-negative bacilli causing meningitis in neurosurgical patients: Significant challenges in ensuring effective antibiotic therapy. J Antimicrob Chemother 2006;57:356-9.

26. Sirnivas D, Veena Kumari HB, Somanna S, Bhagavatula I, Anandappa $\mathrm{CB}$. The incidence of postoperative meningitis in neurosurgery: An institutional experience. Neurol India 2011;59:195-8.

27. Chen SF, Chang WN, Lu CH, Chuang YC, Tsai HH, Tsai NW, et al. Adult Acinetobacter meningitis and its comparison with non-Acinetobacter bacterial meningitis. Acta Neurol Taiwan 2005;14:125-9.

28. Yang TM, Lu CH, Huang CR, Tsai HH, Tsai NW, Lee PY, et al. Clinical characteristics of adult Escherichia coli meningitis. Jpn J Infect Dis 2005;58:168-70.

29. Chang WN, Lu CH, Huang CR, Chuang YC, Tsai NW, Chang CC, et al. Clinical characteristics of post-neurosurgical Klebsiella pneumoniae meningitis in adults and a clinical comparison to the spontaneous form in a Taiwanese population. J Clin Neurosci 2010;17:334-8.

30. Huang CR, Lu CH, Chuang YC, Tsai NW, Chang CC, Chen SF, et al. Adult Pseudomonas aeruginosa meningitis: High incidence of underlying medical and/or postneurosurgical conditions and high mortality rates. Jpn J Infect Dis 2007;60:397-9.

31. Lee MR. Huang YT, Liao CH, Chuang YT, Lin CK, Lee SW, et al. Bacteremia caused by Brevundimonas species at a tertiary care hospital in Taiwan, 2000-2010. Eur J Microbiol Dis 2011;30:1185-91.

32. Murray PR, Baron EJ, Jorgensen JH, Landry ML, Pfaller MA. Manual of Clinical Microbiology. $9^{\text {th }}$ ed. Washington, D.C.: ASM
Mixed infection in post-neurosurgical bacterial meningitis

Press; 2007:749-69.

33. Hsu MS, Liao CH, Huang YT, Liu CY, Yang CJ, Kao KL, et al. Clinical features, antimicrobial susceptibilities, and outcomes of Elizabethkingia meningoseptica (Chryseobacterium meningosepticum) bacteremia at a medical center in Taiwan, 1999-2006. Euro J Clin Microbiol Infect Dis 2011;30:1271-8.

34. Yilmaz G, Aydin K, Bektas D, Caylan R, Koksai I. Cerebellar abscess and meningitis, cause by Shewanella putrefaciens and Klebsiella pneumoniae, associated with chronic otitis media. J Med Microbiol 2007;56:1558-60.

35. Murray PR, Baron EJ, Jorgensen JH, Landry ML, Pfaller MA. Manual of clinical microbiology. $9^{\text {th }}$ ed. Washington, D.C.: ASM Press; 2007:770-802.

36. Moehario LH, Tjoa E, Kiranasa A, Ningsih I, Rosana Y, Karuniawati A. Trends in antimicrobial susceptibility of gram-negative bacteria isolated from blood in Jakarta from 2002 to 2008. J Infect Dev Ctries 2009;3:843-8.

37. Chang WN, Wu JJ, Huang CR, Tsai YC, Chien CC, Lu CH. Identification of viridans streptococcal species causing bacterial meningitis in adults in Taiwan. Eur J Clin Microbiol Infect Dis 2002;21:393-6.

38. Tsai TN, Wu CP, Peng MY, Giian CF, Lee SY, Lu JJ. Short course of linezolid treatment for vancomycin-resistant Enterococcus faecium meningitis. Int J Clin Pract 2006;60:740-1.

39. Frat JP, Gendrine G, Grollier G, Blanc JL, Robert R. Cervical spinal epidural abscess and meningitis due to Prevotella oris and peptostreptococcus micros after retropharyngeal surgery. Intensive Care Med 2004;30:1695.

40. Brook I. Prevotella intermedia meningitis associated with cerebrospinal fluid leakage in an adolescent. Pediatr Infect Dis J $2003 ; 22: 751-3$

41. Brook I. Meningitis and shunt infection caused by anaerobic bacteria in children. Pediatr Neurol 2002;26:99-105.

42. Ngan CC, Tan AL. Bacteroides fragilis meningitis. Singapore Med J 1994;35:283-5.

43. Parmar MS. Pneumocephalus associated with Bacteroides fragilis meningitis. J Postgrad Med 2004;50:272-3.

44. Prasad KN, Mishra AM, Gupta D, Husain N, Husain M, Gupta RK. Analysis of 17 microbial etiology and mortality in patients with brain abscess. J Infect 2006,53:221-7.

45. Brook I. Microbiology of polymicrobial abscesses and implications for therapy. J Antimicrobial Chemother 2002;50:805-10.

46. Federico G, Tumbarello M, Spanu T, Rosell R, Iacoangeli M, Scerrati M, et al. Risk factors and prognostic indicators of bacterial meningitis in a cohort of 3580 postneurosurgical patients. Scan J Infect Dis 2001;33:533-7. 